\title{
Standardizing the Quality of Composts Using Stability and Maturity Indices: The Use of Sawdust and Rice Husks as Compost Feed Stocks
}

\author{
Abdul-Halim Abubakari', Ben K. B. Banful ${ }^{2}$, Laura Atuah ${ }^{2}$ \\ ${ }^{1}$ Department of Horticulture, University for Development Studies, Tamale, Ghana \\ ${ }^{2}$ Department of Horticulture, Kwame Nkrumah University of Science and Technology, Kumasi, Ghana \\ Email: ^bproofa@gmail.com
}

How to cite this paper: Abubakari, A.-H., Banful, B.K.B. and Atuah, L. (2019) Standardizing the Quality of Composts Using Stability and Maturity Indices: The Use of Sawdust and Rice Husks as Compost Feed Stocks. American Journal of Plant Sciences, 10, 2134-2150.

https://doi.org/10.4236/ajps.2019.1012150

Received: November 7, 2019

Accepted: December 7, 2019

Published: December 10, 2019

Copyright $\odot 2019$ by author(s) and Scientific Research Publishing Inc. This work is licensed under the Creative Commons Attribution International License (CC BY 4.0).

http://creativecommons.org/licenses/by/4.0/

\begin{abstract}
Many organic materials found in urban areas of sub-Saharan Africa have not been exploited for the development of feedstock specific quality standards of compost especially for use as soilless media. The objective of this study was to determine feedstock specific quality standard of compost using referenced stability and maturity indices and establish a simple model for predicting compost maturity based on different feedstock. Two sawdust feedstocks from Daniellia oliveri sawdust (single sawdust) and Daniellia oliveri + Chrysophylum albidum sawdust (mixed sawdust) including one rice husk feedstock were composted individually with poultry manure in three volumetric ratios of 2:1, 3:1 and 4:1. The 2:1 Daniellia oliveri sawdust compost achieved acceptable values for stability and maturity parameter at $8^{\text {th }}$ week, and had the highest nitrogen $(\mathrm{N})$ level $(2.46 \%)$ and lowest carbon to nitrogen $(\mathrm{C}: \mathrm{N})$ ratio (15). In terms of associative relationships for single species sawdust compost, total nitrogen (TN) accounted for $93 \%$ of the variation in the C:N content of the compost. In the mixed species sawdust compost, TN explained $87 \%$ of the variation in the C:N. Total nitrogen only explained $77 \%$ of the variation in the C:N content of the rice husk compost. The study established an empirical relationship between $\mathrm{TN}$ and compost maturity and concluded that using stability and maturity indices and their relationships established in this study as standard, compost of higher quality could be obtained within the shortest possible time irrespective of the feedstock used.
\end{abstract}

\section{Keywords}

Compost Maturity, Nutrient Recycling, Waste Management, Soilless Media 


\section{Introduction}

Nutrient recovery from organic waste through re-use and recycling has been proposed for the management of biomass, manures and municipal solid waste (MSW) in the West Africa sub-region, including Ghana [1]-[8]. Composting has received significant attention as an evironmental sustainable way of recovering nutrients from biomass, manures and the organic fraction of MSW. Improper disposal and or burning of biomass are implicated in reducing urban air quality, increasing the greenhouse effect from $\mathrm{CO}_{2}$ and $\mathrm{NO}$ emissions and significantly contributing to global warming and climate change [9]. Dumping of raw manures into water bodies leads to eutrophication and nitrates buildup with adverse consequences on aquatic life [10] [11].

In Ghana, recovery of nutrients from the huge quantities of sawdust, rice husk and poultry manure generated in urban areas could significantly reduce the import bill of inorganic fertilizers and drastically minimize the environmental impact of current waste disposal options. Issaka et al. [12], reported that 3.2 million Mt of manure comprising poultry, cattle, sheep, goat and pig manure is produced annually in Ghana. This constituted 48,695.7 Mt, 43,883.5 Mt, and 20,919.7 Mt equivalents of N, P and K, respectively. In addition, over 366,000 Mt of rice straw and 63,000 Mt of rice husk are produced annually, equivalent to some $2528 \mathrm{Mt}, 990 \mathrm{Mt}$ and $5450 \mathrm{Mt}$ of N, P and K respectively. About $4159 \times 10^{3}$ Mt of crop residues and $360 \times 10^{3} \mathrm{Mt}$ of logging residues (comprising 16\% - 25\% of sawdust) are also produced annually [13].

Unfortunately, most of these wastes generated are not backed by any properly planned disposal schemes or composting systems and therefore become an environmental nuisance with serious adverse effects. But these adverse environmental effects could be eliminated by composting the organic wastes to provide nutrient-rich substrate for crop production. However, production of good quality composts requires good knowledge of the nature of feedstocks and good methods of composting. To ensure universal usage of compost, there is the need to standardize feedstock combinations and composting methods in the way that could influence compost stability and maturity indices [14] [15] [16]. Compost stability refers to the relative impact of the compost product on nutrient availability and the consistency of physical properties of the soil, whilst maturity is defined as the degree or level of completeness of composting. Immature compost may cause N starvation, delayed plant growth and phytotoxicity [17]. They may also contain harmful microbes, weed seeds and have unpleasant odors [18]. Compost quality parameters commonly used as stability and maturity indices include TN, C, C:N ratio, $\mathrm{NO}_{3}-\mathrm{N}, \mathrm{NH}^{4}-\mathrm{N}, \mathrm{EC}, \mathrm{pH}$ and microbial respiration [19]. Stabilized and matured compost $\mathrm{N}$ mineralization has higher levels of $\mathrm{NO}_{3}-\mathrm{N}$ and lower levels of $\mathrm{NH}^{4}-\mathrm{N}$ [18]. Compost temperature and $\mathrm{pH}$ have also been reported as good indicators of the progress of composting. The $\mathrm{pH}$ of compost depends partly on the nature of the initial feedstock. Lignin decomposition is reported to occur at higher temperature. Feedstock of higher C:N is 
known to generate higher $\mathrm{pH}$ and ammonia gas during composting. The $\mathrm{pH}$ levels less than 5 or more than 8 inhibits $\mathrm{N}$ mineralization [20]. Nitrogen release in sawdust for instance was found to correlate positively with total nitrogen and negatively with $\mathrm{pH}[21]$. The EC indicates the soluble salts content of the compost and affects seed germination and root development. Higher EC is noted to cause severe phytotoxicity [22]. Acceptable range of EC is between 0.75 and 2.35. Tender plants are sensitive to EC of 3.5 - 5 and compost of this EC content need to be diluted for tender plants. Compost with EC of 5 or more needs to be applied in lower concentrations or used as mulch for established plants [23]. Although a number of studies have focused on compost quality using the above indices, very few or none have focused on establishing relationship between compost quality indices in different feedstock with varying C:N ratios. It is very important to determine the quality of compost using the above indices and also establish an empirical relationship between stability indices and C:N as an index of compost maturity [19]. Therefore, the objectives of this study were to determine feedstock specific quality standards of compost using referenced stability and maturity indices and establish a simple model for predicting compost maturity for different feedstocks.

\section{Materials and Methods}

The experiment was carried out between April and June, 2014, at the at the Nyankpala campus of the University for Development Studies, Tamale, Ghana. The campus lies on latitude $9^{\circ} 25^{\prime} \mathrm{N}$ and longitude $9^{\circ} 58^{\prime} \mathrm{W}$ and it is $185 \mathrm{~m}$ above mean sea level [24]. Ambient temperature within the study period ranged between $23^{\circ} \mathrm{C}-32^{\circ} \mathrm{C}$. The average relative humidity ranged from $69 \%-85 \%$. There was 8 hours of daily sunshine over the experimental period.

\subsection{Materials, Feedstock and Composting Process}

Poultry manure and 2 feedstocks, namely rice husk and sawdust, were the materials used in the study. The Poultry manure was obtained from a battery cage house of the Animal Science Department at the Nyankpala Campus. Rice husk was obtained from the Savannah Agriculture Research Institute rice milling house, near the Campus and the sawdust was obtained from the Tamale wood market. There were two types of sawdust, namely, the single sawdust (SS) from Daniellia oliveri tree (African copaiba balsam tree) and the mixed sawdust (MS) from Daniellia oliveri and Chrysophylum albidum (white star apple tree) in a 1:1 (v/v) formulation. Compost bins were constructed as wooden boxes with dimensions of $90 \mathrm{~cm} \times 90 \mathrm{~cm} \times 90 \mathrm{~cm}$. The inner wall of the bin was lined with a $200 \mu \mathrm{m}$-plastic films to preserve moisture and heat within the bins. The boxes were closed and kept in the open air during composting. The feedstocks combinations used on dry weight basis as treatments were 2 parts single sawdust: 1 part poultry manure (as 2SS), 3 parts single $s$ sawdust: 1 part poultry manure (as 3SS), 4 parts single sawdust:1 part poultry manure (as 4 SS), 2 parts mixed saw- 
dust: 1 part poultry manure (as $2 \mathrm{MS}$ ), 3 parts mixed sawdust: 1 part poultry manure (as 3MS), 4 parts mixed sawdust: 1 part poultry manure (as 4MS), 2 parts rice husk: 1 part poultry manure (as $2 \mathrm{RH}$ ), 3 parts rice husk: 1 part poultry manure (as $3 \mathrm{RH}$ ) and 4 parts rice husk: 1 part poultry manure (as $4 \mathrm{RH}$ ). Each compost box was filled with a formulated mixture of feedstock plus poultry manure giving a total of nine compost boxes. The mixtures were watered to keep the moisture content at $60 \%$. The mixtures were turned or aerated by scooping out mixtures and refilling so that the top part of the mixtures in box goes to the bottom of the box after turning. Aeration was done three times before the expected maturity period of eight weeks. Compost temperature was measured daily for 60 days using a Thermo-couple thermometer. The rice husk and sawdust feedstock and poultry manure were analyzed for physical and chemical properties before composting. During the composting, a total of twelve compost samples were taken from each treatment for physical and chemical quality analysis at two weekly intervals over 12 weeks. The parameters that were measured during composting included $\mathrm{CO}_{2}$ evolution, electrical conductivity, organic carbon, total nitrogen and mineral nitrogen $\left(\mathrm{NH}_{4}-\mathrm{N}\right.$ and $\left.\mathrm{NO}_{3}-\mathrm{N}\right)$.

\subsection{Analytical Methods}

Total $\mathrm{N}$ was determined using the Kjeldahl digestion method [25]. Organic C was determined by the modified Walkley-Black Wet Oxidation method as outlined by Nelson and Sommers [26]. Organic C in compost and feedstock was determined by the Complete Oxidation procedure adapted from Heanes, [27]. Phosphate, calcium potassium and magnesium were determined by the colorimetery method by Watanabe and Olsen [28]. Electrical conductivity (EC) was determined by inserting the electrode of the EC meter into the compost sample suspension [29]. Crison Basic EC meter CM39P was used for the determination of EC. Crison Basic pH meter PH29P was used for the determination of $\mathrm{pH}$. The concentrations of nutrients in compost and in soil samples (nitrate nitrogen, ammonia nitrogen) were done using UV/VIS spectrophotometer. Nitrate as nitrogen was determined by the Hydrazine Reduction Method [30]. Ammonia as ammonium nitrogen was determined by the Indophenol Blue Method [31]. Lignin and cellulose were determined following the method by Van Soest [32]. Rate of respiration $\left(\mathrm{CO}_{2}\right.$ evolution) was determined following the methods of [33]. Media moisture and temperature were determined in-situ, using a Thermo-couple thermometer and portable moisture meter respectively (Hanna instruments, Madrid Spain).

\subsection{Data Analyses}

Data on quality of feedstock treatments (poultry manure, sawdust, rice husk) were analyzed using analysis of variance (ANOVA), in Gentstat version 9.2. Least significant differences (LSD) were calculated and the probability of treatment means significantly different was set at $p=0.05$. Data on compost quality 
were analyzed by ANOVA using STATISTIX version 10 and Tukeys Honestly Significant differences were calculated at $5 \%$ level of probability $(\mathrm{p}=0.05)$. Relationships between stability indices were established using correlation and regression analysis.

\section{Results}

\subsection{Physico-Chemical Properties of Poultry Manure and Feedstocks}

Poultry manure as compared to the other feedstocks, was significantly higher $(p$ $=0.017)$ in $\mathrm{N}(4.37 \%), \mathrm{P}(1.05 \%),(p=0.044), \mathrm{K}(4.10 \%) ; p=0.030, \mathrm{Ca}(4.47 \%)$; $p=0.010, \mathrm{Mg}(3.1 \%) ; p=0.002$ and higher in density $\left(0.5 \mathrm{~g} / \mathrm{cm}^{3}\right) ; p=0.003$. For the other parameters, all feedstock had similar nutrient content. The MS was highest in moisture content $(12.1 \%) ; p=0.001$, total organic carbon (TOC) (45.1\%); $p<0.001$, cellulose (42.1\%); $p<0.001$ and lignin $(23.7 \%) ; p=0.040$. The SS was highest in EC $\left(8.7 \mathrm{mS} / \mathrm{cm}^{3}\right) ; p=0.001$ (Table 1). The SS feedstock had the highest C:N ratio of 170 than MS feedstock (110.19) and RH feedstock (106.23).

\subsection{Temperature Profile during Composting}

The 2SS and $3 \mathrm{SS}$ maintained temperature above $40^{\circ} \mathrm{C}$ (thermophilic temperature) for one week before falling below $40^{\circ} \mathrm{C}$ (mesophilic). The $4 \mathrm{SS}$ could only maintain the temperature for four days. Turning the compost resulted in increasing the temperature to $43^{\circ} \mathrm{C}$. The highest peak temperature $\left(51^{\circ} \mathrm{C}\right)$ was attained in $2 \mathrm{SS}$ compost at 43 days and $50^{\circ} \mathrm{C}$ for $4 \mathrm{SS}$ at 41 days. After 43 days, the

Table 1. Physico-chemical properties of poultry manure, rice husk, single sawdust and mixed sawdust.

\begin{tabular}{ccccccc}
\hline Properties & Poultry manure & Rice husk & SS & MS & LSD & $p$-value \\
\hline N (\%) & $4.37 \pm 0.28$ & $0.38^{\mathrm{a}}$ & $0.25^{\mathrm{b}}$ & $0.41^{\mathrm{a}}$ & 0.085 & 0.017 \\
$\mathrm{P}(\%)$ & $1.05 \pm 0.03$ & $0.43^{\mathrm{a}}$ & $0.21^{\mathrm{b}}$ & $0.15^{\mathrm{c}}$ & 0.015 & 0.044 \\
$\mathrm{~K}(\%)$ & $4.10 \pm 0.11$ & $1.81^{\mathrm{a}}$ & $1.34^{\mathrm{b}}$ & $0.72^{\mathrm{c}}$ & 0.093 & 0.030 \\
$\mathrm{Ca}(\%)$ & $4.47 \pm 0.08$ & $0.82^{\mathrm{c}}$ & $1.26^{\mathrm{b}}$ & $1.32^{\mathrm{a}}$ & 0.060 & 0.010 \\
$\mathrm{Mg}(\%)$ & $3.19 \pm 0.02$ & $0.73^{\mathrm{b}}$ & $0.91^{\mathrm{a}}$ & $0.66^{\mathrm{c}}$ & 0.028 & 0.002 \\
Moisture (\%) & $9.45 \pm 0.50$ & $7.10^{\mathrm{c}}$ & $11.30^{\mathrm{b}}$ & $12.13^{\mathrm{a}}$ & 0.550 & 0.001 \\
EC (mS/cm $)$ & $4.00 \pm 0.30$ & $3.55^{\mathrm{b}}$ & $8.73^{\mathrm{a}}$ & $3.41^{\mathrm{b}}$ & 0.230 & 0.001 \\
Density (g/cm $\left.{ }^{3}\right)$ & $0.50 \pm 0.01$ & $0.25^{\mathrm{b}}$ & $0.28^{\mathrm{a}}$ & $0.25^{\mathrm{b}}$ & 0.015 & 0.003 \\
OC (\%) & $25.40 \pm 1.00$ & $40.37^{\mathrm{c}}$ & $42.50^{\mathrm{b}}$ & $45.18^{\mathrm{a}}$ & 1.082 & $<0.001$ \\
Cellulose (\%) & $23.87 \pm 0.08$ & $27.74^{\mathrm{c}}$ & $32.75^{\mathrm{b}}$ & $42.11^{\mathrm{a}}$ & 0.093 & $<0.001$ \\
Lignin (\%) & $11.77 \pm 0.70$ & $21.68^{\mathrm{c}}$ & $23.15^{\mathrm{b}}$ & $23.74^{\mathrm{a}}$ & 0.225 & 0.040 \\
C:N & 5.81 & 106.23 & 170 & 110.19 & & \\
\hline
\end{tabular}

*Adopted and modified from Abubakari et al., 2017. 
temperature dropped below $40^{\circ} \mathrm{C}$ and close to ambient temperature of $35^{\circ} \mathrm{C}$. (Figure 1(a)).

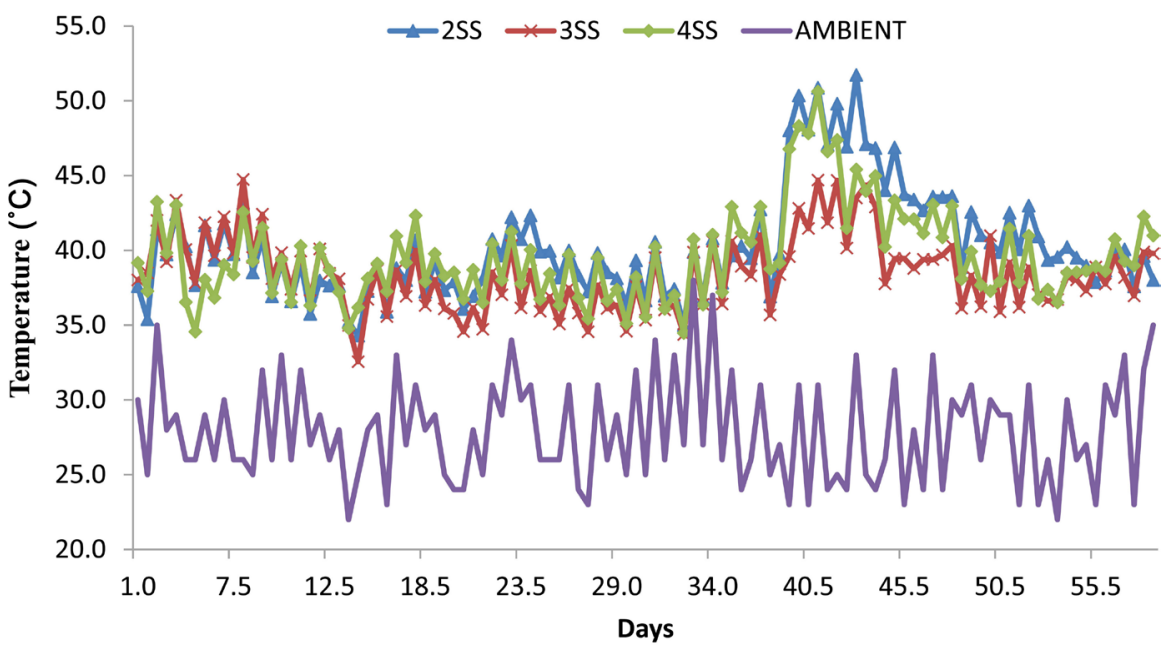

(a) SINGLE SAWDUST COMPOSTS

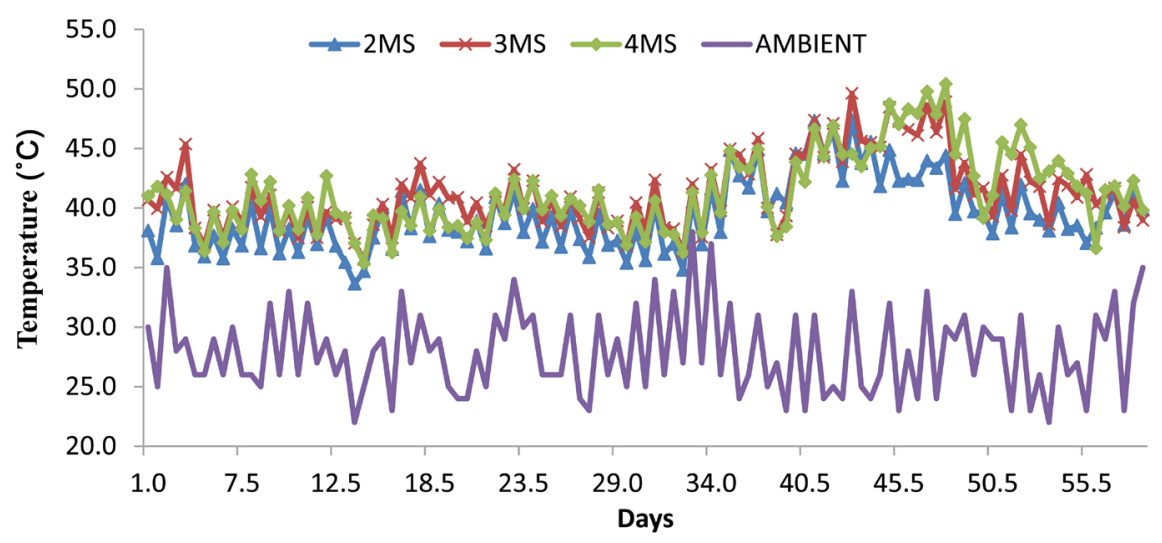

(b) MIXED SAWDUST COMPOSTS

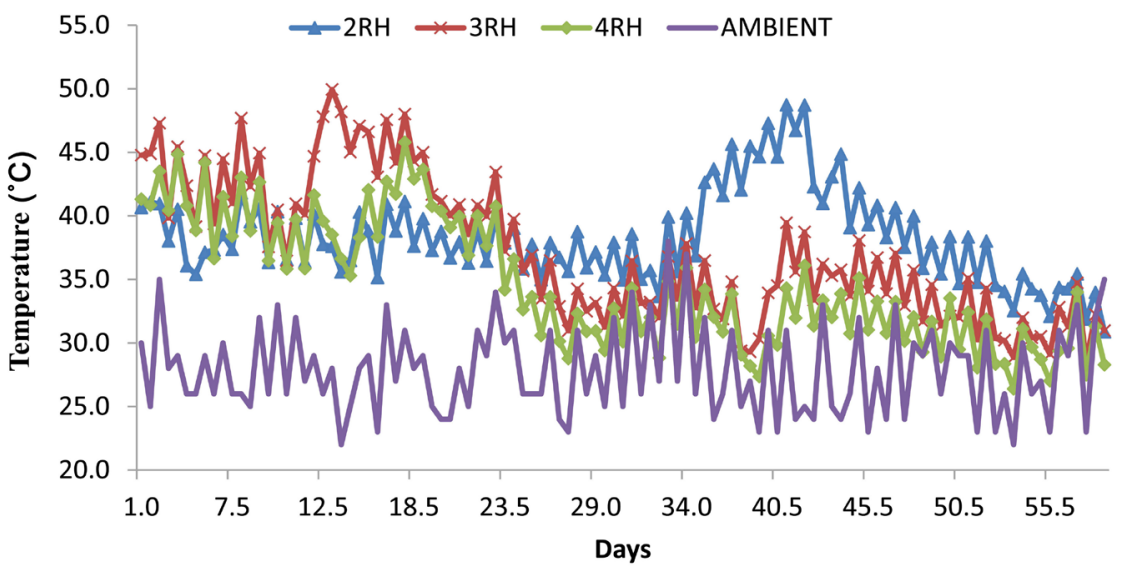

(c) RICE HUSK COMPOSTS

Figure 1. (a) Temperatures of the various single species composts in comparison with the ambient temperature; (b) Temperatures of the various mixed species composts in comparison with the ambient temperature; (c) Temperatures of the various rice husk composts in comparison with the ambient temperature. 


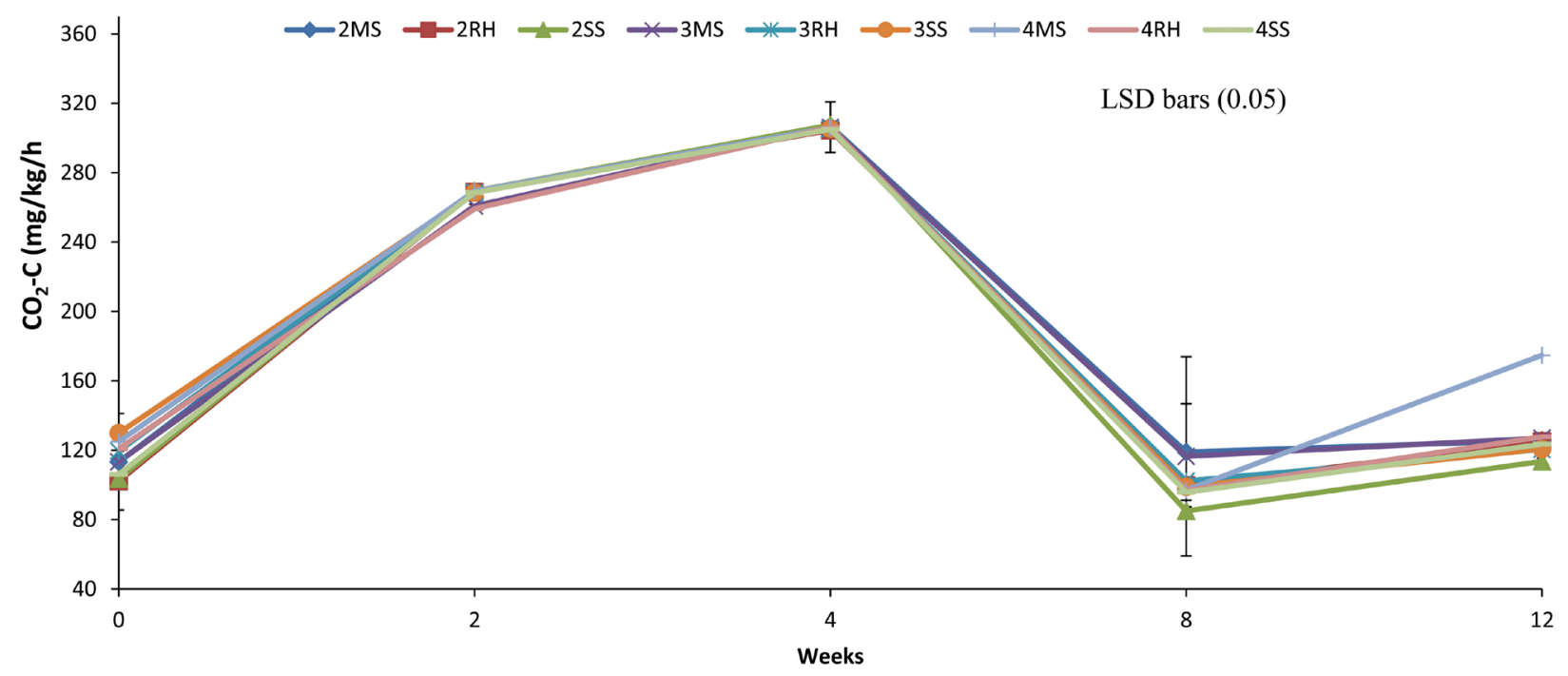

Figure 2. $\mathrm{CO}_{2}$ evolution trends for the different compost types over the period of composting. 
were no significant differences in $\mathrm{pH}$ values between $2^{\text {nd }}$ and $6^{\text {th }}$ week of composting. At $8-12^{\text {th }}$ week, the $3 \mathrm{MS}$ and $4 \mathrm{MS}$ based composts had neutral $\mathrm{pH}$ higher than all other treatments. The $3 \mathrm{RH}, 4 \mathrm{RH}$ and $2 \mathrm{MS}$ based composts were slightly acidic, with $\mathrm{pH}$ (6.8) lower than all other treatments (Figure 3).

\subsection{Changes in Electrical Conductivity}

At the start of composting of the 2SS based compost had the highest EC of 3.9, significantly greater than $3 \mathrm{SS}$ and $4 \mathrm{SS}$ based composts, which had the least EC of 2.7 and 2.2, respectively (Figure 4(a)). After $2^{\text {nd }}$ week of composting, all three SS based composts had similar ECs. After $4^{\text {th }}$ week of composting however, 4SS based compost had significantly higher EC than 3SS based compost which had the lowest. Showing consistency, after $8^{\text {th }}$ week of composting, 4 SS based compost continued to have the highest EC, significantly greater than those of 2SS and 3SS based composts. However, at $12^{\text {th }}$ week of composting, all three SS based composts recorded similar EC (Figure 4(a)). From the start of composting till $8^{\text {th }}$ week of composting, all the three MS based compost had similar EC. After $4^{\text {th }}$ and $8^{\text {th }}$ week of composting, the $2 \mathrm{MS}$ and $3 \mathrm{MS}$ based compost had significantly higher EC than the 4MS based compost which had EC value of $1.7 \mathrm{mS} / \mathrm{cm}^{3}$. However, after $8^{\text {th }}$ week of composting, all three MS based composts had similar EC values (Figure 4(b)).

At the start of composting, the $2 \mathrm{RH}$ based compost had EC of 3.9 significantly higher than $3 \mathrm{RH}$ and $4 \mathrm{RH}$ based composts with ECs of 2.9 and 2.8 respectively. After $2^{\text {nd }}$ and $4^{\text {th }}$ weeks of composting, the $2 \mathrm{RH}$ and $3 \mathrm{RH}$ based composts had significantly lower EC than $4 \mathrm{RH}$ based compost. However, at $8^{\text {th }}$ week and $12^{\text {th }}$ week of composting, all the three rice husk composts had similar EC (Figure 4(c)).

\subsection{Stability and Maturity Indices of the Mature Compost}

At $4^{\text {th }}$ week of composting, $4 \mathrm{MS}$ based compost shows the highest C:N ratio,

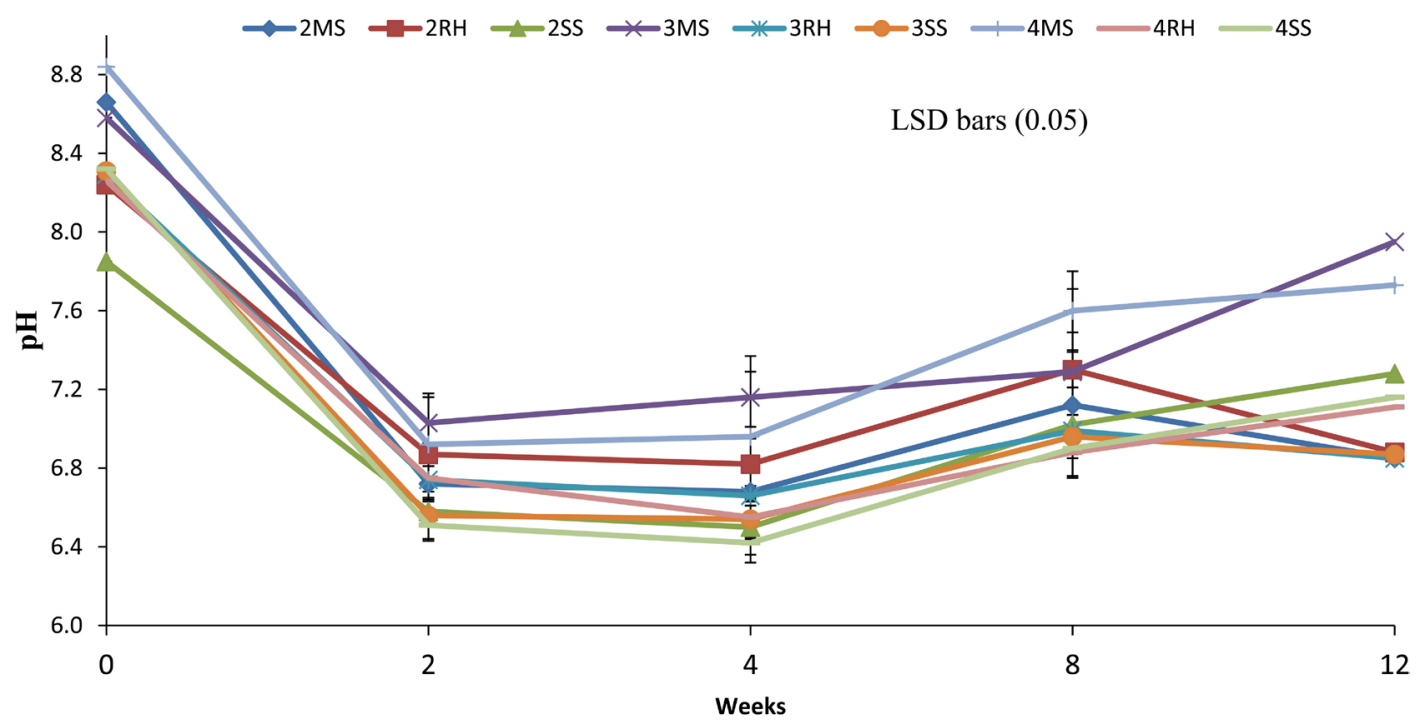

Figure 3. $\mathrm{pH}$ profile of the compost types over the period of composting. 


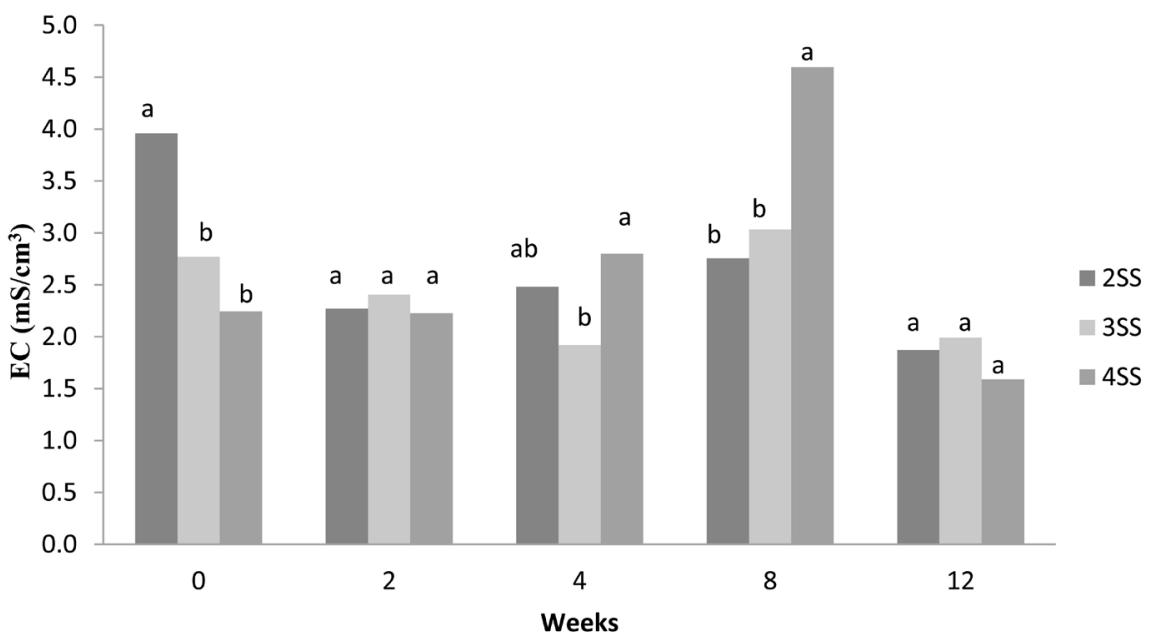

(a)

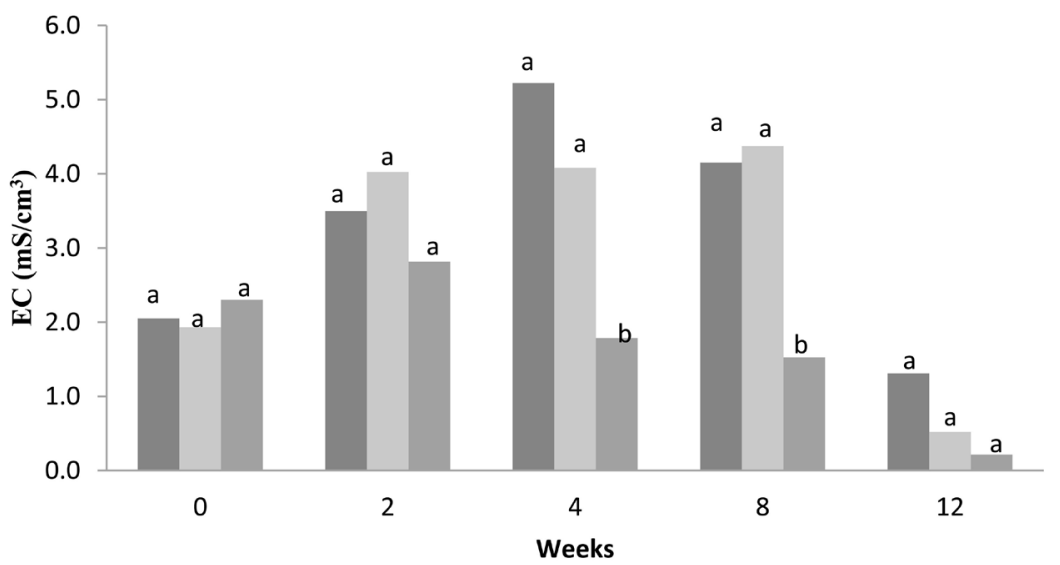

$2 \mathrm{MS}$ 3MS 4MS

(b)

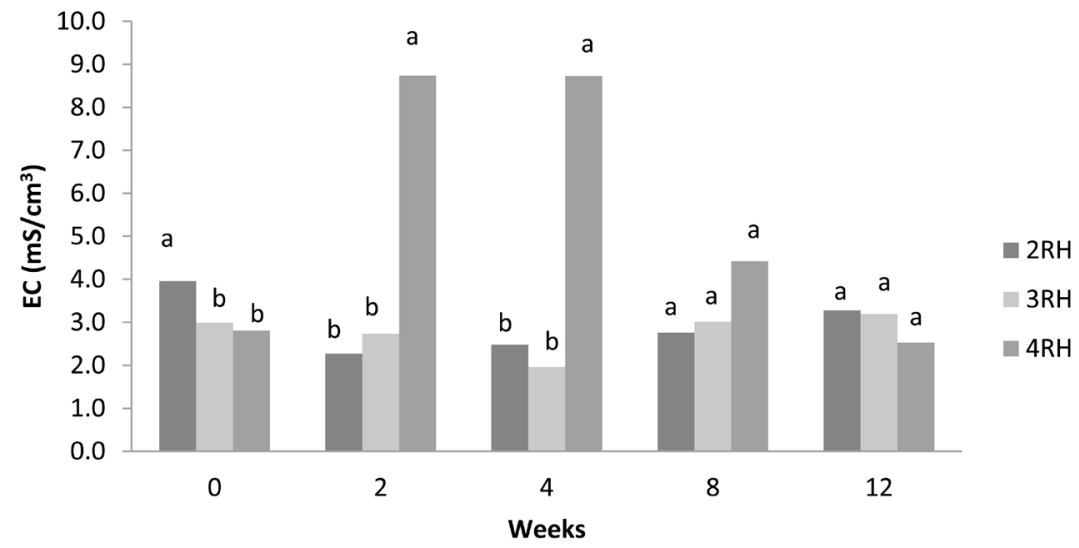

(c)

Figure 4. (a) Electrical conductivity profile of single species compost for 12 weeks of composting; (b) Electrical conductivity profile of mixed species Daniellia oliveri + chrysophylum albidum compost for 12 weeks of composting; (c) Electrical conductivity profile of rice husk compost for 12 weeks of composting.

significantly greater than the rest of the composts, except that of 3MS based compost which was similar (Table 2). The least C:N ratio was shown by $2 \mathrm{RH}$ 
based compost. At $8^{\text {th }}$ week of composting, 4MS based compost continued to show the highest $\mathrm{C}: \mathrm{N}$ ratio, significantly greater than all the other composts. The least C:N ratio was shown by $2 \mathrm{RH}$ based compost. However, at $12^{\text {th }}$ week of composting, $4 \mathrm{RH}$ based compost had the highest $\mathrm{C}: \mathrm{N}$ ratio, significantly greater than the rest of the composts. The least $\mathrm{C}: \mathrm{N}$ ratio was recorded by $2 \mathrm{SS}$ based compost. In comparison to the referenced quality standards, all the composts had attained maturity at $12^{\text {th }}$ week of composting, except $4 \mathrm{RH}$ based compost which had C:N ratio still above the standard (Table 2).

\subsection{Compost Quality at Maturity}

The 2SS based compost showed significantly highest total nitrogen content (2.46\%), whereas the $4 \mathrm{RH}$ based compost showed the least (1.32\%). The $2 \mathrm{MS}$ based compost had the highest carbon content $(39.62 \%)$, while the $4 \mathrm{RH}$ base compost had the lowest carbon content (33.28\%). The highest C losess occurred in $4 \mathrm{RH}$ compost and the least $\mathrm{C}$ losses occurred in $4 \mathrm{SS}$. The $\mathrm{NH}_{4}-\mathrm{N}$ level was highest in 2MS based compost $(215.98 \mathrm{mg} / \mathrm{kg}$ ) and lowest in $4 \mathrm{SS}$ based compost $(23.45 \mathrm{mg} / \mathrm{kg}$ ). The $2 \mathrm{SS}$ based compost showed the lowest C:N value (15.76) whereas the $4 \mathrm{RH}$ based compost had the highest $\mathrm{C}: \mathrm{N}$ value of $26: 23$. The $2 \mathrm{SS}$ had the highest EC of $1.87 \mathrm{mS} / \mathrm{cm}^{3}$ whereas $4 \mathrm{MS}$ had the lowest EC value of 0.22 $\mathrm{mS} / \mathrm{cm} 3$ (Table 3).

\subsection{Relationships between Maturity Indices and Maturation during Composting}

In terms of associative relationships, for single species sawdust compost, the following correlations were found; Total nitrogen (TN) and $\mathrm{pH}(\mathrm{r}=-0.80, p<$

Table 2. C:N ratio value as affected by duration of composting.

\begin{tabular}{cccc}
\hline & & C:N ratio \\
\cline { 2 - 4 } Compost type & 4 weeks & $\mathbf{8}$ weeks & 12 weeks \\
\hline 2SS & 29.69 & 24.55 & 15.76 \\
$4 S S$ & 32.48 & 30.45 & 18.83 \\
$4 \mathrm{SS}$ & 31.22 & 28.50 & 20.25 \\
$2 \mathrm{MS}$ & 30.15 & 29.34 & 22.50 \\
$3 \mathrm{MS}$ & 40.74 & 30.69 & 20.79 \\
$4 \mathrm{MS}$ & 43.38 & 36.00 & 20.83 \\
$2 \mathrm{RH}$ & 26.43 & 24.25 & 19.31 \\
$3 \mathrm{RH}$ & 28.08 & 27.73 & 20.44 \\
$4 \mathrm{RH}$ & 32.33 & 33.18 & 26.23 \\
$p$-value & 0.005 & 0.030 & $<0.001$ \\
LSD (0.05) & 5.166 & 3.81 & 3.43 \\
\hline
\end{tabular}

Reference compost quality standard, C:N ratio of 15 - 25 (Sæbøa and Ferrini, 2006). 
Table 3. Summary of quality indices of the mature composts at 12 weeks of composting.

\begin{tabular}{|c|c|c|c|c|c|c|c|c|}
\hline \multirow{2}{*}{ COMPOST } & \multicolumn{3}{|c|}{ Macro nutrients (\%) } & \multicolumn{2}{|c|}{$\begin{array}{c}\text { Mineral nitrogen } \\
(\mathrm{mg} / \mathrm{kg})\end{array}$} & \multirow{2}{*}{$\mathrm{C}: \mathrm{N}$} & \multirow{2}{*}{$\mathrm{pH}$} & \multirow{2}{*}{$\begin{array}{c}\mathrm{EC} \\
\left(\mathrm{mS} / \mathrm{cm}^{3}\right)\end{array}$} \\
\hline & $\mathbf{N}$ & $\mathrm{C}$ & $\begin{array}{c}\mathrm{C}^{* *} \\
\text { Losses }\end{array}$ & $\mathrm{NH}_{4}-\mathrm{N}$ & $\mathrm{NO}_{3}-\mathrm{N}$ & & & \\
\hline $2 \mathrm{SS}$ & 2.46 & 38.40 & 8.6 & 38.28 & 1117.81 & 15.76 & 7.28 & 1.87 \\
\hline $3 S S$ & 2.11 & 39.31 & 6.92 & 38.80 & 1138.6 & 18.83 & 6.85 & 1.99 \\
\hline $4 \mathrm{SS}$ & 2.04 & 40.99 & 2.63 & 23.45 & 1126.27 & 20.25 & 7.11 & 1.59 \\
\hline $2 \mathrm{MS}$ & 1.82 & 39.62 & 13.28 & 215.98 & 811.60 & 22.50 & 6.85 & 1.31 \\
\hline $3 \mathrm{MS}$ & 2.02 & 41.05 & 9.87 & 81.16 & 379.23 & 20.79 & 7.95 & 0.52 \\
\hline $4 \mathrm{MS}$ & 2.02 & 40.90 & 10.22 & 102.91 & 394.85 & 20.83 & 7.73 & 0.22 \\
\hline $2 \mathrm{RH}$ & 1.68 & 31.711 & 11.25 & 76.45 & 827.89 & 19.31 & 6.85 & 0.33 \\
\hline $3 \mathrm{RH}$ & 1.61 & 31.88 & 20.28 & 163.94 & 958.51 & 20.44 & 6.85 & 0.58 \\
\hline $4 \mathrm{RH}$ & 1.32 & 33.28 & 16.93 & 212.78 & 567.64 & 26.23 & 7.11 & 0.86 \\
\hline$p$-value & $<0.001$ & $<0.001$ & - & 0.001 & $<0.001$ & 0.1031 & 0.001 & $<0.001$ \\
\hline Tukey's HSD (0.05) & 0.6891 & 5.2662 & - & 165.84 & 367.62 & 9.7644 & 05153 & 0.1254 \\
\hline $\begin{array}{l}\text { Compost } \\
\text { Standard }{ }^{* * *}\end{array}$ & - & - & - & $<500$ & $200-1000$ & $15-25$ & $6-8$ & $0-4$ \\
\hline
\end{tabular}

$\mathrm{C}^{* *}=$ losses based on initial feedstock carbon value; ${ }^{* *}$ Sæbøa and Ferrini, 2006. 2SS = two parts of single species sawdust to one part poultry manure; $3 S S=$ three parts of single species sawdust to one part poultry manure; $4 \mathrm{SS}$ = four parts of single species sawdust to one part poultry manure; $2 \mathrm{MS}=$ two parts mixed species sawdust to one part poultry manure; $3 \mathrm{MS}=$ three parts mixed species sawdust to one part poultry manure; $4 \mathrm{MS}$ = four parts mixed species sawdust to one part poultry manure; $2 \mathrm{RH}=$ two parts rice husk to one part poultry manure; $3 \mathrm{RH}=$ three parts rice husk to one part poultry manure; $4 \mathrm{RH}=$ four parts rice husk to one part poultry manure.

0.001, $\mathrm{n}=40) ; \mathrm{TN}$ and $\mathrm{C}: \mathrm{N}(\mathrm{r}=-0.96, p<0.001, \mathrm{n}=40)$; TN and $\mathrm{CO}_{2}(\mathrm{r}=$ $-0.83, p<0.001, \mathrm{n}=40)$ and $\mathrm{CO}_{2}$ and $\mathrm{pH}(\mathrm{r}=-0.91, p<0.001, \mathrm{n}=40)$.

For mixed species sawdust compost, the following correlations were found. Total $\mathrm{N}$ and $\mathrm{pH}(\mathrm{r}=0.567, p<0.001, \mathrm{n}=40)$; TN and $\mathrm{C}: \mathrm{N}(\mathrm{r}=-0.94, p<0.001$, $\mathrm{n}=40)$; $\mathrm{TN}$ and $\mathrm{CO}_{2}(\mathrm{r}=-0.73, p<0.001, \mathrm{n}=40)$ and $\mathrm{CO}_{2}$ and $\mathrm{pH}(\mathrm{r}=-0.56, p$ $<0.001, \mathrm{n}=40$ ).

For rice husk compost, TN was significantly and positively correlated with $\mathrm{pH}$ $(\mathrm{r}=0.656, p<0.001, \mathrm{n}=40)$ but negatively correlated with $\mathrm{C}: \mathrm{N}(\mathrm{r}=-0.880, p<$ $0.001, \mathrm{n}=40)$ and $\mathrm{CO}_{2}(\mathrm{r}=-0.642, p<0.001, \mathrm{n}=40)$. The $\mathrm{CO}_{2}$ was negatively correlated with $\mathrm{pH}(\mathrm{r}=-0.710, p<0.001, \mathrm{n}=40)$.

Total nitrogen was related to the $\mathrm{C}: \mathrm{N}$ content of the compost depending on the base material of the compost. For single species sawdust compost, total nitrogen accounted for $93 \%$ of the variation in the C:N content of the compost in the relationship;

$$
Y_{(C / N)}=50.099-14.502 X_{(T N)} ; R^{2}=0.93 ; p<0.001 ; n=40,
$$

However, for mixed species sawdust compost, total nitrogen explained $87 \%$ of the variation in the $\mathrm{C}: \mathrm{N}$ content of the compost in the relationship; 


$$
Y_{(C / N)}=58.455-19.541 X_{(T N)} ; R^{2}=0.87 ; p<0.001 ; n=40,
$$

Total nitrogen explained $77 \%$ of the variation in the C:N content of the rice husk compost in the relationship;

$$
Y_{(C / N)}=47.126-16.795 X_{(T N)} ; R^{2}=0.77 ; p<0.001 ; n=40,
$$

\section{Discussion}

\subsection{Chemical Characterization of Feedstock and Compost}

MS feedstock was found to have higher OC and more lignin than SS feedstock and rice husk. However, the SS feedstock had the highest initial C:N compared to MS and RH. In characterizing feedstock for composting, the C:N ratio is critical as it determines the length of the thermophilic phases and also the maturity of and stability periods of the final compost. The optimum C:N ratio for matured and stabilized compost is 12:1 to 15:1 [19]. A C:N ratio less than 10:1 indicates situations of incomplete composting associated with higher levels of $\mathrm{N}$ manures. C:N ratio values of more than 25:1 indicate presence of raw carbonaceous materials which when applied to soil results in severe $\mathrm{N}$ drawdown [19]. Leconte et al. [14], characterized poultry manure and found that it had high $\mathrm{N}$ concentration $(\mathrm{N}=3.7 \%)$ and low organic carbon (29\%) compared to sawdust $(\mathrm{N}=0.6$, and $\mathrm{C}=53.2 \%)$ and rice husk $(\mathrm{N}=0.4 \%$ and $\mathrm{C}=42.0 \%)$. Poultry manure was also found to a have high $\mathrm{pH}(8.0)$ and $\mathrm{Ca}(19.4 \%)$ concentration.

\subsection{Compost Temperature and $\mathrm{CO}_{2}$ Evolution}

Leconte et al. [14], reported that, the high temperatures associated with the composting process was due largely to organic matter breakdown, increasing microbial population and activity and reducing supply of $\mathrm{O}_{2}$. During the first 4 5 days, the compost pile is characterized by fermentation which results in enhanced breakdown of highly lignified carbonaceous materials. This stage is associated with significant multiplication of microorganisms. The nature of carbonaceous materials ultimately determines the length of the thermophilic phase [15]. Higher values of respiration $(340-466 \mathrm{mg} / \mathrm{kg} / \mathrm{h})$ were reported at early stages of composting decreasing to $37-90 \mathrm{mg} / \mathrm{kg} / \mathrm{h}$ by maturity period of compost [14]. Although increasing microbial respiration was correlated with increasing compost temperature [34], Leconte [14] found the reverse and attributed that to thermic inertia which was thought to be the result of exothermic hydrolysis.

\subsection{Compost Moisture, $\mathrm{pH}$ and Electrical Conductivity}

Decreased $\mathrm{pH}$ may result from anaerobic conditions in compost which leads to the accumulation of organic acids such as acetic acid and propionic acid. The presence of these acids in the potting media causes the media to become toxic to seeds and seedling development [35]. Generally, the $\mathrm{pH}$ of a compost depends partly on the nature of the initial feedstocks. Feedstocks of higher C:N ratio are 
known to generate higher $\mathrm{pH}$ and ammonia gas during composting whiles $\mathrm{N}_{2} \mathrm{O}$ emissions are known to be highest at low $\mathrm{pH}$. Moreover, there is stabilization of $\mathrm{pH}$ as a result of ammonia volatilization and $\mathrm{H}^{+}$release from microbial nitrification [15]. Therefore, for $\mathrm{N}$ mineralization to be uninhibited, the $\mathrm{pH}$ levels should not be less than 5 or greater than 8 [20]. In the present study, nitrogen release in sawdust was positively correlated with $\mathrm{TN}$ and negatively with $\mathrm{pH}$ [21].

Furthermore, the EC values at the end of composting for all the nine compost types were lower than the referenced compost quality standard, an indication that the composts could not be a source of toxicity to seeds or seedlings that would be planted in them. EC, a measure of soluble salts content of the compost, affects seed germination and root development and higher levels cause severe phytotoxicity [36]. If the EC is less than 0.75 , the media will require nutrient supplementation. Acceptable range of EC is between 0.75 and 2.35. Consequently, in the present study, $2 \mathrm{RH}, 3 \mathrm{RH}, 3 \mathrm{MS}$ and $4 \mathrm{MS}$ composts would require nutrient supplementation since their EC values were below 0.75. Increase in EC could be due to release of mineral salts that occur during the active phase of composting [37]. Composts with EC of 5 or more needs to be applied in lower concentrations or used as mulch for established plants [23].

\subsection{Quality and Stability Indices of Mature Compost}

The quality of compost produced in this study was influenced not only by the nature of bulking materials (carbonaceous materials) but by the amount of poultry manure ( $\mathrm{N}$ level) incorporated. The 2:1 ratio of SS to poultry manure (33\% of poultry manure addition) resulted in the highest $\mathrm{N}$ level of $2.46 \%$ in SS based compost compared to 3:1 ratio (or $25 \%$ addition of poultry manure) with $\mathrm{N}$ level of $2.11 \%$ and $4: 1$ ratio (or $20 \%$ poultry manure addition) with $2.02 \% \mathrm{~N}$ level. In the RH based composts, the same pattern was seen in the RH based compost where higher addition of poultry manure resulted in higher $\mathrm{N}$ level in the matured compost. However, in the MS based composts, the reverse is the case where higher addition of compost actually resulted in lower levels of $\mathrm{N}$ in the final compost. In SS based composts, C losses were higher in 2SS compost where there was higher amount of poultry manure incorporated during composting and the least carbon losses occurred in 4SS composted where there was lower addition of poultry manure was used during composting. In the MS and RH based composts, carbon losses did not appear to be related to the amount of poultry manure added during composting. The quality of composts produced in the present study is comparable to composts produced elsewhere using different feedstocks [14] [38] [39] [40]. However, the SS based compost had higher $(1117.81 \mathrm{mg} / \mathrm{kg}-1138.6 \mathrm{mg} / \mathrm{kg})$ than recommended levels of $\mathrm{NO}_{3}-\mathrm{N}$. All the $\mathrm{C}: \mathrm{N}$ values found in the compost produced except $4 \mathrm{RH}$, were within levels acceptable for stabilized compost (15:1 - 25:1). In the present study, correlation analysis highlighted significant relationships among the compost maturity in- 
dices. In all the different feedstock used, $\mathrm{TN}$ was always positively correlated with $\mathrm{pH}$, but negatively correlated with $\mathrm{C}: \mathrm{N}$ and $\mathrm{CO}_{2}$. This finding was significant as it indicated that as the degradation of carbon leads to the accumulation of nitrogen, $\mathrm{pH}$ reaches alkaline levels. This is associated with matured compost and $\mathrm{CO}_{2}$ values decline because of reduced microbial activity associated with maturity. The empirical relationship established between $\mathrm{TN}$ and C:N indicates that although TN is the dominant factor explaining variation of $\mathrm{C}: \mathrm{N}$ and hence compost maturity, the extent to which TN could explain variation in $\mathrm{CN}$ depended on the nature of carbonaceous materials.

\section{Conclusions}

The study has clearly demonstrated that irrespective of the nature of the feedstocks, quality composts with acceptable stability and maturity indices could be derived within the time frame of 8 to 12 weeks.

In this study, the 2SS achieved maturity and stability indices at 8 weeks of composting, had the highest $\mathrm{N}$ level (2.46) and lowest C:N ratio (15). Furthermore, the $\mathrm{NH}_{4}-\mathrm{N}, \mathrm{pH}$ and $\mathrm{EC}$ were also within the recommended quality indices specified for highly stabilized quality composts. As a consequence of this, there is the potential to convert wastes that cause environmental pollution into very useful media for agricultural use in open fields and in greenhouses which currently has very limited media alternatives for quality crop production.

\section{Conflicts of Interest}

The authors declare no conflicts of interest regarding the publication of this paper.

\section{References}

[1] Drechsel, P. and Gyiele, L. (1998) On-Farm Research on Sustainable Land Management in Sub Saharan Africa: Approaches, Experiences, and Lessons. IBSRAM Proceedings No. 19. IBSRAM, Bangkok.

[2] Kindness, H. (1999) Supply and Demand for Soil Ameliorants in Peri-Urban Kumasi. Kumasi Natural Resources Management Project, KNUST/NRI/DFID.

[3] Cofie, O., Montangero, A., Strauss, M. and Zubruegg, C. (2003) Co-Composting of Faecal Sludge and Municipal Organic Waste for Urban and Peri-Urban Agriculture in Kumasi, Ghana. Final Report (Unpublished) Submitted to the French Foreign Ministry.

[4] Drechsel, P., Cofie, O., Fink, M., Danso, G., Zakari, F.M. and Vasquez, R. (2004) Closing the Rural-Urban Nutrient Cycle. Options for Municipal Waste Composting in Ghana. Final Scientific Report Submitted to IDRC. https://www.iwmi.cgiar.org/africa/westafrica/

[5] Cofie, O., Gordana Kranjac-Berisavljevic, O. and Drechsel, P. (2005) The Use of Human Waste for Peri-Urban Agriculture in Northern Ghana. Renewable Agriculture and Food Systems, 20, 73-80. https://doi.org/10.1079/RAF200491

[6] Danso, G., Drechsel, P., Fialor, S. and Giordano, M. (2006) Estimating the Demand for Municipal Waste Compost via Farmers' Willingness-to-Pay in Ghana. Waste 
Management, 26, 1400-1409. https://doi.org/10.1016/j.wasman.2005.09.021

[7] Cofie, O., Abraham, E.M., Olaleye, A.O. and Larbi, T. (2008) Recycling Human Excreta for Urban and Peri-Urban Agriculture in Ghana. In: Parrot, L., Ed., Agricultures et development urbain en Afrique subsaharienne, Environment et enjeux sanitaires, L'Harmattan, Paris, 191-200.

[8] Adamtey, N., Cofie, O., and Forster, D. (2009) An Economic Analysis of Co-Compost Fertilizer Mixture (Comlizer) Use on Maize Production in the Accra Plain of Ghana. Research Progress Report. Submitted to IWMI and Eawag/Sandec, 10 .

[9] Mensah-Bonsu and Owusu-Ansah (2011) State of the Environment in Kumasi. In: Future of the Tree, University Printing Press, Kumasi, 176-194.

[10] Bationo, A., Hartemink, A., Lungu, O., Naimi, M., Okoth, P., Smaling, E. and Thiaombiano, L. (2006) African Soils: Their Productivity and Profitability of Fertilizer Use. The African Fertilizer Summit, Abuja, Nigeria, 9-13 June 2006.

[11] Amoah, P., Drechsel, P., Abaidoo, R.C. and Ntow, W.J. (2006) Pesticide and Pathogen Contamination of Vegetables in Ghana's Urban Markets. Archives of Environmental Contamination and Toxicology, 50, 1-6.

https://doi.org/10.1007/s00244-004-0054-8

[12] Issaka, R.N., Buri, M.M., Tobita, S.T., Nakamura, S. and Adjei, E.O. (2012) Indigenous Fertilizing Materials to Enhance Soil Productivity in Ghana, Soil Fertility and Integrated Nutrient Management-Global Perspective.

[13] Duku, M.H., Gua, S.C. and Essel, B.H. (2011) Biochar Production Potential in Ghana-A Review. Renewable and Sustainable Energy Reviews, 15, 3539-3551. https://doi.org/10.1016/j.rser.2011.05.010

[14] Leconte, M.C., Mazzarino, M.J., Satti, P., Iglesias, M.C. and Laos, F. (2009) Co-Composting Rice Hulls and/or Sawdust with Poultry Manure in NE Argentina. Waste Management, 29, 2446-2453. https://doi.org/10.1016/j.wasman.2009.04.006

[15] Gao, M., Liang, F., Yu, A., Li, B. and Yang, L. (2010) Evaluation of Stability and Maturity during Forced-Aeration Composting of Chicken Manure and Sawdust at Different C/N Ratios. Chemosphere, 78, 614-619. https://doi.org/10.1016/j.chemosphere.2009.10.056

[16] Bakry, M., Lamhamedi, M.S., Caron, J., Margolis, H., Abidine, A.Z., Bellaka, H.M. and Stowe, D.C. (2012) Are Composts from Shredded Leafy Branches of Fast-Growing Forest Species Suitable as Nursery Growing Media in Arid Regions? New Forests, 43, 267-286. https://doi.org/10.1007/s11056-011-9280-x

[17] CCQC (2001) Compost Maturity Index. http://www.calrecycle.ca.gov/organics/products/quality/compmaturity.pdf

[18] Kotaro, K., Miura, N., Tabuchi, H. and Nioh, I. (2005) Evaluation of Maturity of Poultry Manure Compost by Phospholipid Fatty Acids Analysis. Biology and Fertility of Soils, 41, 399-410. https://doi.org/10.1007/s00374-005-0855-6

[19] Saebo, A. and Ferrini, F. (2006) The Use of Compost in Urban Green Areas-A Review for Practical Application. Urban Forestry \& Urban Greening, 4, 159-169. https://doi.org/10.1016/j.ufug.2006.01.003

[20] Amlinger, F., Götz, B., Dreher, P., Geszti, J. and Weissteiner, C. (2003) Nitrogen in Biowaste and Yard Waste Compost: Dynamics of Mobilisation and Availability-A Review. European Journal of Soil Biology, 39, 107-116. https://doi.org/10.1016/S1164-5563(03)00026-8

[21] Leconte, M.C., Mazzarino, M.J., Satti, P. and Crego, M.P. (2011) Nitrogen and 
Phosphorus Release from Poultry Manure Composts: The Role of Carbonaceous Bulking Agents and Compost Particle Sizes. Biology and Fertility of Soils, 47, 897-906. https://doi.org/10.1007/s00374-011-0591-z

[22] Wilson, S.B. and Stoffella, P.J. (2001) Evaluation of Compost as an Amendment to Commercial Mixes Used for Container-Grown Golden Shrimp Plant Production. HortTechnology, 11, 31-35. https://doi.org/10.21273/HORTTECH.11.1.31

[23] Brewer, L.J. and Sullivan, D.M. (2001) Maturity and Stability Evaluation of Composted Yard Trimmings. Compost Science \& Utilization, 11, 96-112. https://doi.org/10.1080/1065657X.2003.10702117

[24] Savannah Agricultural Research Institute (SARI) (1997) Soil Survey. Savanna Agricultural Research Institute, Nyankpala, 9-22.

[25] Okelabo, J.R., Gathua, K.W. and Woomer, P.L. (1993) Laboratory Methods of Soil and Plant Analysis: A Working Manual. TSBF, Nairobi, Kenya.

[26] Nelson, D.W. and Sommers, L.E. (1982) Total Carbon, Organic Carbon and Organic Matter. In: Page, A.L., et al., Eds., Methods of Soil Analysis: Part 2. Chemical and Microbiological Properties, ASA Monograph, 539-579.

[27] Heanes, D.L. (1984) Determination of Total Organic C in Soils by an Improved Chromic Acid Digestion and Spectrophotometric Procedure. Communications in Soil Science and plant Analysis, 15, 1191-1213. https://doi.org/10.1080/00103628409367551

[28] Watanabe, F.S. and Olsen, S.R. (1965) Test of an Ascorbic Acid Method for Determining Phosphorus in Water and Sodium Bicarbonate Extracts from Soil. Soil Science Proceedings, 29, 677-678. https://doi.org/10.2136/sssaj1965.03615995002900060025x

[29] Rowell, D.L. (1994) Soil Science, Methods and Applications. Longman Scientific \& Technical, London.

[30] Cataldo, D.A., Haroon, M., Shroder, L.E. and Younger, V.L. (1975) Rapid Colorimetric Determination of Nitrate in Plant Tissue by Nitration of Salicylic Acid. Communication in Soil and Science and Plant Analysis, 6, 71-80. https://doi.org/10.1080/00103627509366547

[31] Koroleff, F. (1976) Determination of Nutrients. In: Grasshoff, K., Ed., Methods of Seawater Analysis, Verlag Chemie, Weinhein, 317.

[32] Van Soest, P.J. (1963) Use of Detergents in the Analysis of Fibrous Feeds. II. A Rapid Method for the Determination of Fiber and Lignin. Journal-Association of Official Analytical Chemists, 46, 829-835.

[33] Iannotti, D.A., Pang, T., Toth, B.L., Elwell, D.L., Keener, H.M. and Hoitink, H.A.J. (1993) A Quantitative Respirometric Method for Monitoring Compost Stability. Compost Science \& Utilization, 1, 52-65. https://doi.org/10.1080/1065657X.1993.10757890

[34] Tiquia, S.M., Richard, T.L. and Honeyman, M.S. (1996) Carbon, Nutrient, and Mass Loss during Composting. Nutrient Cycling in Agroecosystems, 62, 15-24. https://doi.org/10.1023/A:1015137922816

[35] McClintock, N.C. and Diop, A.M. (2005) Soil Fertility Management and Compost Use in Senegal's Peanut Basin. International Journal of Agricultural Sustainability, 3, 79-91. https://doi.org/10.1080/14735903.2005.9684746

[36] Wilson, S.B. and Stoffella, P.J. (2001) Evaluation of Compost as an Amendment to Commercial Mixes Used for Container-grown Golden Shrimp Plant Production. HortTechnology, 11, 31-35. https://doi.org/10.21273/HORTTECH.11.1.31 
[37] Gomez-Brandon, M., Lazcano, C. and Domınguez, J. (2008) The Evaluation of Stability and Maturity during the Composting of Cattle Manure. Chemosphere, 70, 436-444. https://doi.org/10.1016/j.chemosphere.2007.06.065

[38] Ali, M., Griffiths, J.A., Williams, K.P. and Jones, D.L. (2007) Evaluating the Growth Characteristics of Lettuce in Vermicompost and Green Waste Compost. European Journal of Soil Biology, 43, S316-S319. https://doi.org/10.1016/j.ejsobi.2007.08.045

[39] Jayasinghe, G.Y., Liyana Arachchi, I.D. and Yoshihiro, T. (2010) Evaluation of Containerized Substrates Developed from Cattle Manure Compost and Synthetic Aggregates for Ornamental Plant Production as a Peat Alternative. Resources, Conservation and Recycling, 54, 1412-1418. https://doi.org/10.1016/j.resconrec.2010.06.002

[40] Abubakari, A.-H., Atuah, L. and Banful, B. (2015) Growth and Yield Response of Lettuce to Irrigation and Growth Media from Composted Sawdust and Rice Husk. Journal of Plant Nutrition, 41, 221-232. 